\title{
Mammalian organogenesis in deep time: tools for teaching and outreach
}

\author{
Marcelo R. Sánchez-Villagra ${ }^{1}$ and Ingmar Werneburg $1,2,3,4^{*}$
}

\begin{abstract}
Mammals constitute a rich subject of study on evolution and development and provide model organisms for experimental investigations. They can serve to illustrate how ontogeny and phylogeny can be studied together and how the reconstruction of ancestors of our own evolutionary lineage can be approached. Likewise, mammals can be used to promote 'tree thinking' and can provide an organismal appreciation of evolutionary changes. This subject is suitable for the classroom and to the public at large given the interest and familiarity of people with mammals and their closest relatives. We present a simple exercise in which embryonic development is presented as a transformative process that can be observed, compared, and analyzed. In addition, we provide and discuss a freely available animation on organogenesis and life history evolution in mammals. An evolutionary tree can be the best tool to order and understand those transformations for different species. A simple exercise introduces the subject of changes in developmental timing or heterochrony and its importance in evolution. The developmental perspective is relevant in teaching and outreach efforts for the understanding of evolutionary theory today.
\end{abstract}

Keywords: Development, Ontogeny, Embryology, Phylogeny, Heterochrony, Recapitulation, Placentalia, Human

\section{Background}

Mammals are a diverse group in which to examine development and evolution, and besides the mouse and the rat used in biomedical research, provide subjects based on which experimental (Harjunmaa et al. 2014; Montandon et al. 2014; Parsons et al. 2015) and comparative (Cooper et al. 2014) studies have provided major insights. They can effectively serve to illustrate evolution in the classroom and to the public at large given the interest and familiarity of people with the group (Prothero 2007; Asher 2012).

The mammalian morphological diversity, also called phenotypic disparity, is large and encompasses forms as different as bats, whales, mice, humans, the egg-laying echidna and platypus, and the kangaroo. This disparity emerges through the evolution of organogenesis, the portion of individual development in which the general 'body plan' as well as species-specific features emerge

\footnotetext{
*Correspondence: ingmar-werneburg@outlook.com

${ }^{2}$ Senckenberg Center for Human Evolution and Palaeoenvironment (HEP) at Eberhard Karls Universität, Sigwartstr. 10, 72074 Tübingen, Germany Full list of author information is available at the end of the article
}

(Gilbert 2013), followed by the growth process. In placental mammals, organogenesis takes place mostly in the uterus, whereas in monotremes and marsupials a very immature hatchling or newborn, respectively, develops further either close to the mother or in its pouch (Werneburg and Spiekman in press). Many features can be used to characterize developing mammals externally, and each can evolve. Among them are aspects of the integument such as hair, the limbs, and structures of the head such as the external ear or the eyelids (Schoenwolf 2008; Werneburg and Sánchez-Villagra 2011; Werneburg et al. 2016).

The exercise presented here deals with an aspect of development that although not trivial, does not require a rich anatomical background, as a brief introduction using pictures and drawings of embryonic series can easily allow students to extract basic information on external organs. The use of pictorial documentation is tied to a fundamental aspect of anatomical research, one with deep historical roots. During the golden age of comparative embryology, around 1900, hundreds of embryos were illustrated in beautiful treatises that showed different stages in the ontogeny of a species (Hopwood 2005, 
Table 1 Selected normal plates of vertebrate development

\begin{tabular}{|c|c|c|}
\hline Major groups & Species & Reference \\
\hline Mammalia, Placentalia & Capreolus capreolus & Sakurai (1906) \\
\hline Sauropsida, Aves & Gallus gallus ("domesticus") & Keibel and Abraham (1900) \\
\hline Mammalia, Placentalia & Homo sapiens & Keibel and Elze (1908) \\
\hline Amphibia, Gymnophiona & Hypogeophis rostratus and H. alternus (Fig. 51-55) & Brauer (1899) \\
\hline Sauropsida, Squamata & Lacerta agilis & Peter (1904) \\
\hline Dipnoi & Lepidosiren paradoxa & Kerr (1909) \\
\hline Amphibia, Caudata & Necturus maculosus & Eycleshymer and Wilson (1910) \\
\hline Mammalia, Placentalia & Nycticebus coucang ("tardigradus") & Hubrecht and Keibel (1907) \\
\hline Mammalia, Placentalia & Oryctolagus ("Lepus") cuniculus & Minot and Taylor (1905) \\
\hline Dipnoi & Protopterus annectens & Kerr (1909) \\
\hline Amphibia, Anura & Rana pipiens & Shumway (1940) \\
\hline Mammalia, Placentalia & Rattus norvegicus & Henneberg (1937) \\
\hline Mammalia, Placentalia & Spermophilus citellus & Völker -Brünn (1922) \\
\hline Chondrichthyes, Neoselachii & Squalus acanthias & Scammon (1911) \\
\hline Mammalia, Placentalia & Sus scrofa & Keibel (1897) \\
\hline Mammalia, Monotremata & Tachyglossus aculeatus & Semon (1894) \\
\hline Amphibia, Caudata & Triton ("Molge") vulgaris & Glaesner (1925) \\
\hline Sauropsida, Aves & Vanellus cristatus & Grosser and Tandler (1909) \\
\hline
\end{tabular}

See Fig. 3 for the phylogenetic arrangement of the species

2007). The plates are transformation series occurring in the life of an animal. Different organs first appear while others differentiate, so that the species-specific features arise gradually, in a particular sequence of events.

The exercise consists of the comparison of developmental series of diverse species, as documented in illustrations from which anatomical information can be extracted. It deals with features of embryology of vertebrates treated in some works in developmental genetics, but from a whole-organism perspective. The latter concerns mostly the 'pattern', referred to as the phenomenological aspect of development (Hanken 2015), as opposed to the approaches that aim at discovering the 'processes' or mechanisms behind those patterns (Cubo 2000; Richardson et al. 2009). The organismal perspective (Maier 1999) has a long tradition and involves sophisticated methods of morphometrics and knowledge of anatomy. Current curricula at university and high-school level tend to concentrate on molecular tools and genetics to the detriment of organismal biology.

The comparison of developmental series serves as an introduction on how differences among adults-how morphological transformations in evolution-are the result of developmental repatterning. Repatterning can concern timing (heterochrony), space (heterotopy), quantity (heterometry), and kind (heterotypy) (Arthur 2011). Examples of these can be seen in an examination of organogenesis. The evolutionary changes in developmental timing, heterochrony, have been a focus of research for decades (Raff 1996; Smith 2001; Maxwell and Harrison 2009).

An exercise on comparative organogenesis in vertebrates

The activity is designed for use in lecture-type courses but is scalable to large courses and can be performed including discussions in $45 \mathrm{~min}$. It is implementable without assistance in a class with as many students as the number of developmental series depictions provided (Table 1; Additional files 1-18) or in multiples of that number should pairs or groups of 3 or more students deal with each species. There are five steps to be followed:

1. Students are given each a set of drawings of one species, which they are expected to examine in a temporal sequence from early to late, based on the obvious progressing nature of development. In the Additional files 1-18 to this article, we provide plates of 'normal tables' of development (Keibel 1897) which can be used for this exercise. All specimens on the plates have numbers that serve to order them. In the case of small student groups and where the logistics permit, it is recommended that after being given the complete plates, students cut out each individual without their number and the sets of the series are exchanged among student groups. That way students then have to establish the order of a new set of individual embryos, having been previously exposed to one complete, ordered series of another species. 
Instead of presenting sets of developmental series uniform in terms of the number of specimens and the time window portrayed, we suggest to provide the students with the plates from the original references (Table 1; Additional files 1-18), as this has the advantage of facing the student with a situation more similar to that encountered in actual comparative embryological work. This means having a different number of specimens for each species. An equal number would provide the false impression that each 'stage' depicted is comparable to the corresponding one in the series of the other species. The original plates serve also to illustrate the difficulties of establishing stages, and how each of the original authors (Table 1) had a different opinion on how many specimens best characterize a species' development, and the different and subjective criteria to identify 'stages'. This exercise is good training against typological thinking, which has had a negative influence on studies of development and evolution. Evolution is about variation and not about fixed types or archetypes (Richardson et al. 1999; Werneburg 2009).

As a general reference for our own species, Fig. 1 illustrates a subset of human embryos encompassing approximately the first 2 months after conception. It is recommended that all students examine the human series.

2. Students examine and subsequently label several anatomical features and their occurrence in the different stages, either digitally or in provided printouts (Additional files 1-18). For this purpose, the students are provided a reference figure which identifies basic structures such as the eye, somites, tail, lower jaw, forelimb, hind limb, and branchial arches (Fig. 2). Further character descriptions and illustrations can be found at https://en.wikipedia.org/wiki/Standard Event_System. (access: 2016-11-25). This is basically an exercise in identifying structures that are homologous, and as such emphasizes homology thinking, a central aspect in evolutionary biology that benefits from the tree-thinking perspective (Ereshefsky 2012; Wagner 2016), also central here.

3. The resulting series from step 1 , revised after closer examination resulting from step 2 , are then placed together and compared. This comparison reveals the commonality in the general pattern of differentiation, but also the differences among species in the sequence of appearance of structures. Likewise, it makes clear how some structures form in some groups and not in others; e.g., limbs in land vertebrates (tetrapods) and fins in fishes or scales in sauropsids and hairs in mammals.
4. After a phylogeny-free first comparison, subsequently the species examined are organized in a provided phylogenetic framework (Fig. 3). The subsequent group discussion is about how patterns emerge (which characters are common and different among species) that can be best explained as determined by evolutionary history (see below).

5. The activity is rounded up by showing the video discussed in the following section of this article.

The exercise is useful in showing depictions of real organisms, the common pattern of development of humans, and their evolutionary relatives. An example of general similarity between evolutionary and developmental transformation (Macrini 2002; Martin and Ruf 2009; Asher 2012; Ramírez-Chaves et al. 2016; Werneburg and Spiekman in press), is the fact that the hand in some stages of mammalian foetuses, including human ones, looks like a paddle (e.g., Fig. 1k) and thus resembles superficially that of our aquatic ancestors. This commonality among species in the transformation series contrasts with the differences in the static stage represented by the adult. Here it is important for the instructor to emphasize to the students that there are no steps in ontogeny, but instead that each depicted embryo represents a single, living individual with features of its own that allow it to survive. The individuals represented in the series are examples of populations, so that not only interspecific but also intraspecific variability occurs (de Jong et al. 2009). Furthermore, a clear definition of characters is always important to make reliable comparisons among the specimens of one developmental series as well as among different species. The detected differences among species highlight the importance of studying embryonic features to understand evolutionary changes. Among other subjects of potential discussion are the relation between developmental and evolutionary transformation, recapitulation, and developmental repatterning.

The idea that 'ontogeny recapitulates phylogeny' is widespread among students and the public and it is the classic subject of recapitulation. For recapitulation to happen, an addition at the end of the original or ancestral developmental sequence or trajectory would have to occur (Fig. 4; Wägele 2005). That ontogeny does not simply recapitulate phylogeny is very well accepted. Only specific characters or character complexes, such as gill slits in mammals (Fig. 1e), can be recapitulated and, in that case, always perform a necessary functional task during ontogeny (Werneburg et al. 2013b). However, none of the embryos resembles an adult of any other species, so examination of the provided depictions of developmental series makes the case clearly. Deviations from 
a

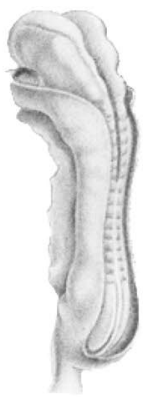

e
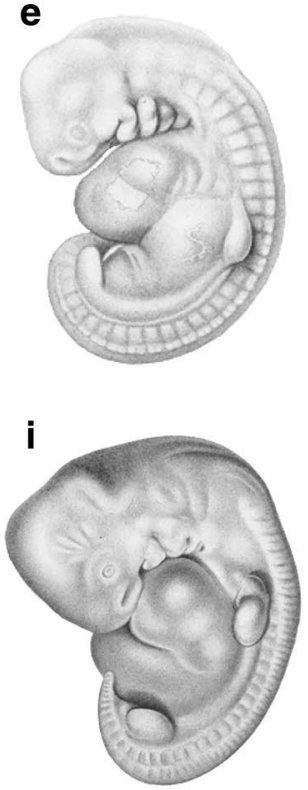

m

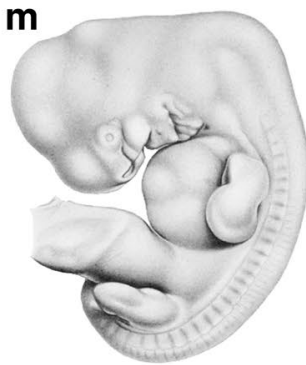

q

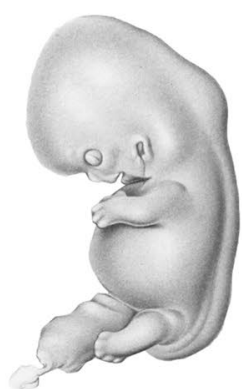

b

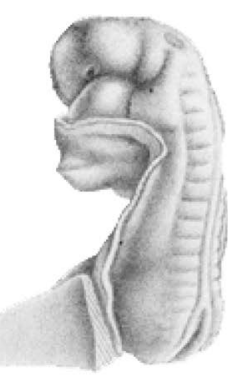

f

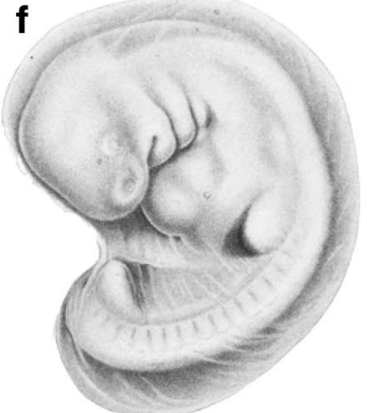

j

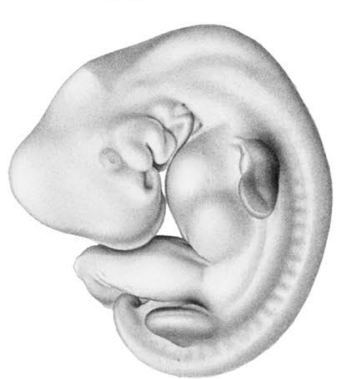

n

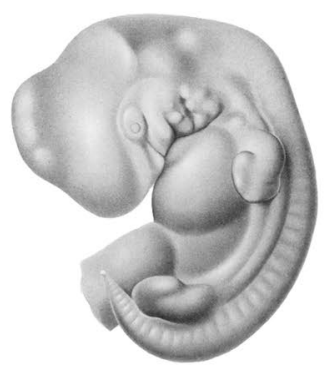

r

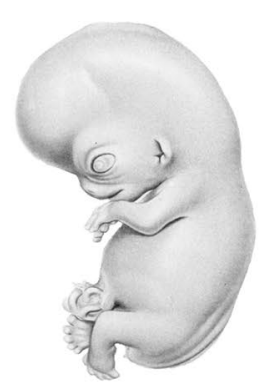

C

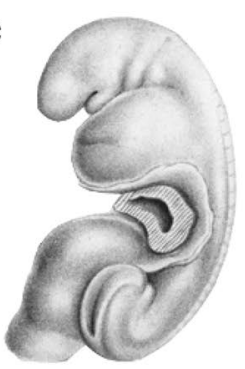

g

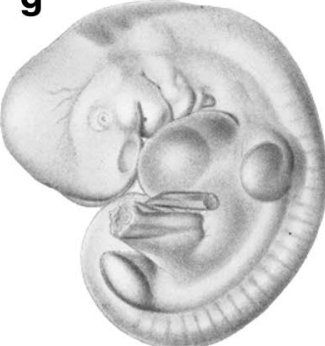

k

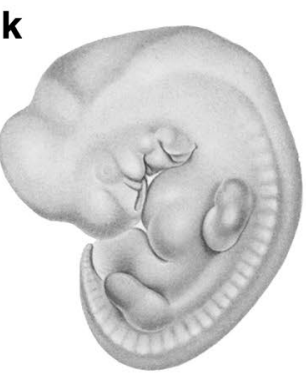

o

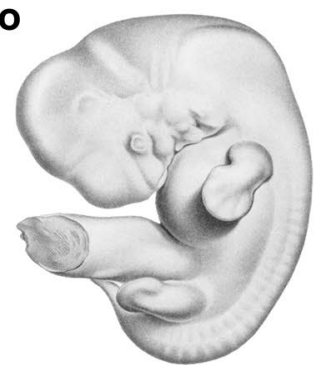

s

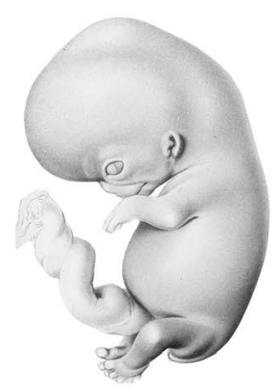

d

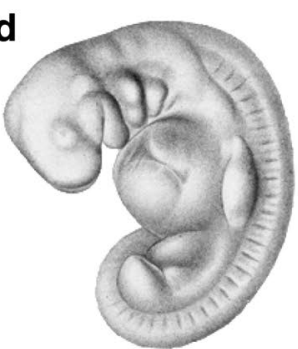

h

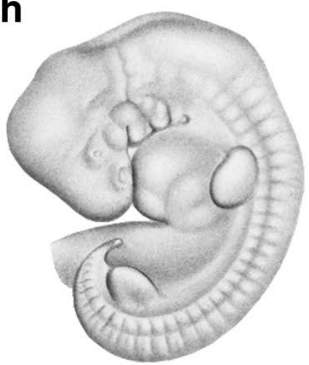

I

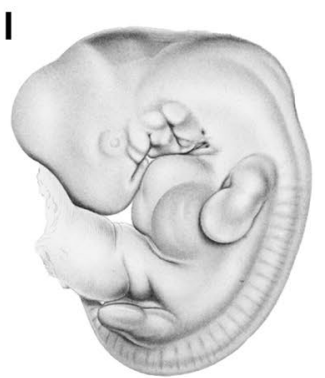

p

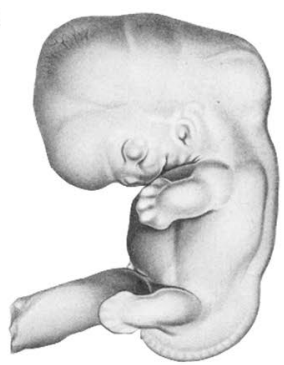

t

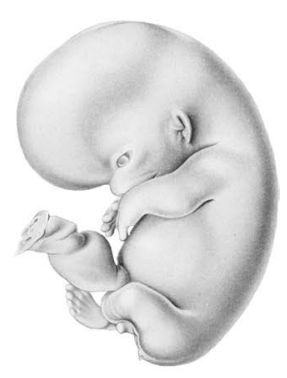

Fig. 1 Selected human embryos from the "Normentafel" of Keibel and Elze (1908). Approximate age of embryos based on O'Rahilly and Müller (1987): a 22 days, $\mathbf{b} 24$ days, $\mathbf{c} 25$ days, $\mathbf{d} 26$ days, 28 days, $\mathbf{f} 32$ days, $\mathbf{g} 33$ days, h-I $37-41$ days, $\mathbf{m}-\mathbf{p}$ around 44 days, $\mathbf{q} 47$ days, 50 days, 

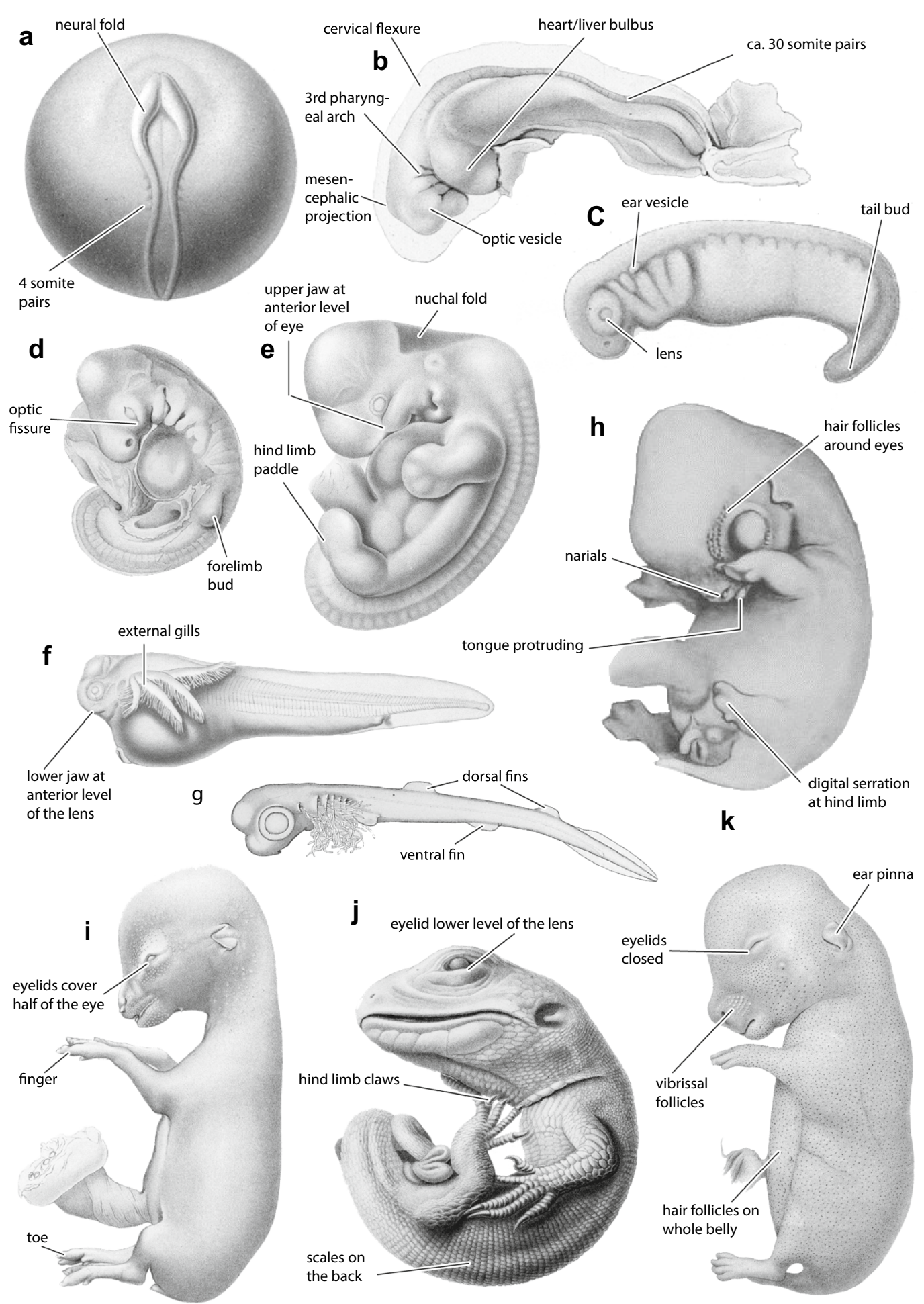

Fig. 2 Selected vertebrate embryos of different developmental periods taken (except for $\mathbf{h}$ ) from the "Normentafeln zur Entwicklungsgeschichte der Wirbeltiere" edited by Franz Keibel from 1897 to 1938 (Hopwood 2007) and selected discrete embryological characters as defined in the Standard Event System (Werneburg 2009; https://en.wikipedia.org/wiki/Standard_Event_System). a Common mudpuppy Necturus maculosus (Eycleshymer and Wilson 1910); b, i roe deer Capreolus capreolus (Sakurai 1906); c Triturus vulgaris (Glaesner 1925); d, j Lacerta agilis (Peter 1904); e Sundra slow loris Nycticebus coucang (Hubrecht and Keibel 1907); f South American lungfish Lepidosiren paradoxa (Kerr 1909); $\mathbf{g}$ Spiny dogfish Squalus acanthias (Scammon 1911); h goat Capra hircus (Tsukaguchi 1912); k rabbit Oryctolagus cuniculus (Minot and Taylor 1905). Embryos not to scale 


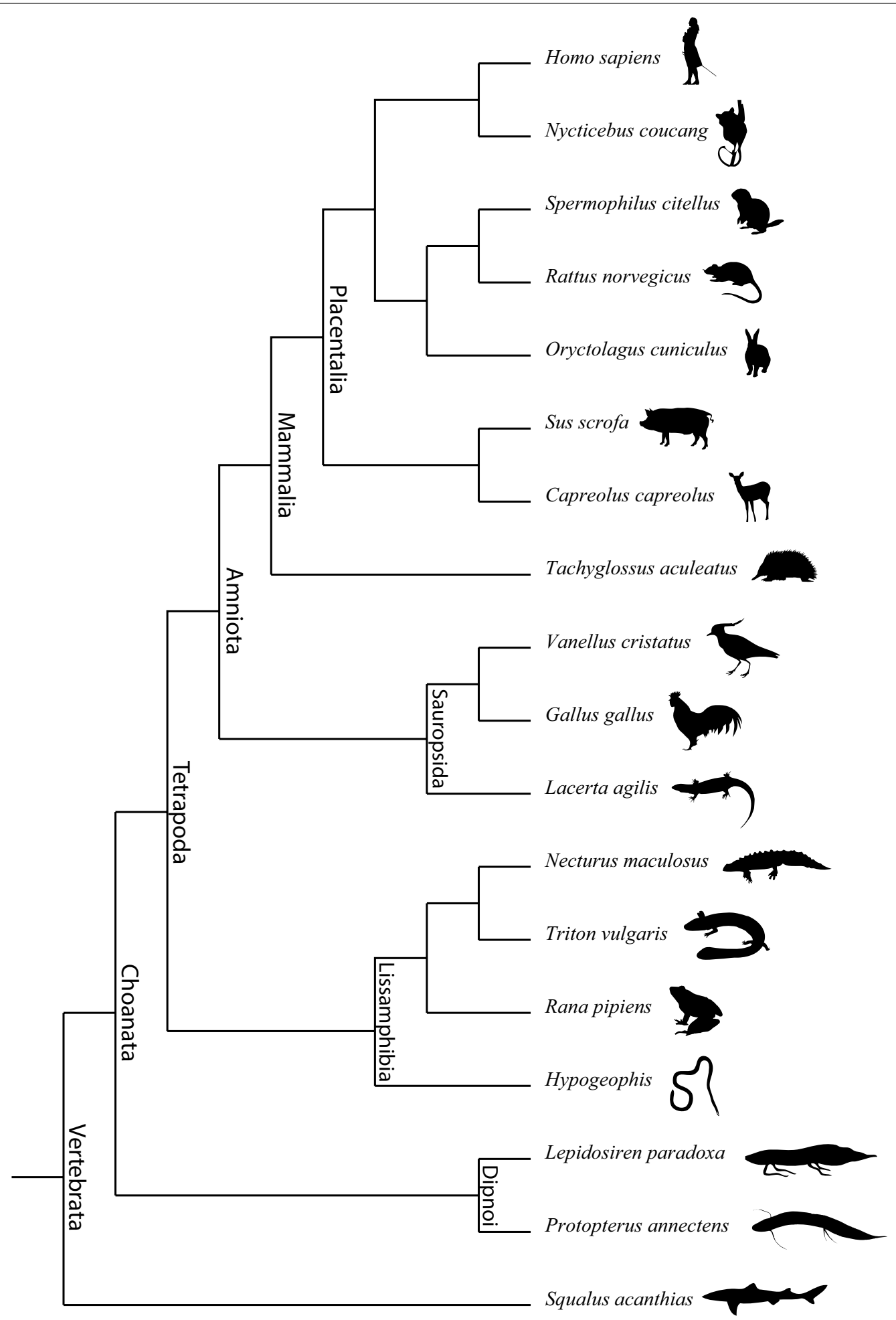

Fig. 3 Phylogenetic framework of the species for which developmental series are provided in the Additional file 1. Many natural history museums still depict evolutionary patterns as 'orthogenetic', and thus as a linear and directed sequence from ancestor to descendant, including even the classic example of horses [discussed by MacFadden et al. (2012)]. This kind of representation is wrong, as the pattern is actually a branching one. This mistake communicates antiquated knowledge and perpetuates misconceptions about evolution. People tend to see evolution as a story with a beginning, middle, and an end [discussed by Baum and Smith (2012)]. Phylogenetic trees challenge this view, showing a branching and fractal pattern instead of linearity, and with one beginning and many ends 


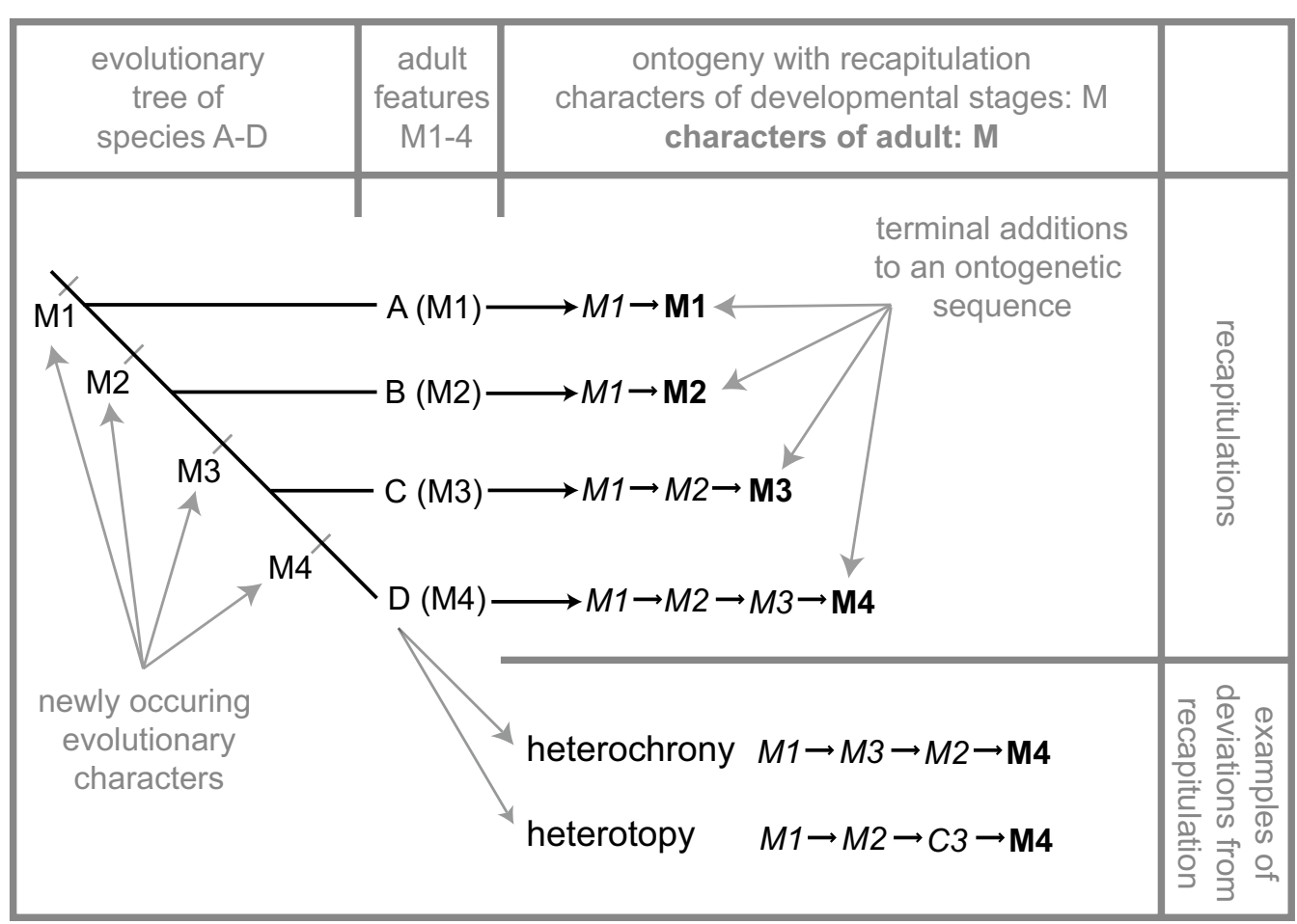

Fig. 4 A consistent pattern of terminal addition in the evolution of ontogenetic sequences, as illustrated here for four species in abstract terms, leads to ontogenetic recapitulation. Each species is characterized by a common developmental trajectory consisting of the first step, M1 $\rightarrow$ M1. A new feature is added at the end of the sequence. In this ideal case, species " $\mathrm{D}$ ", the one with the most specialized condition, contains in its ontogeny the sequence of evolutionary transformations. But there can be deviations from the recapitulatory pattern. Features in the sequence can move around, one or more of them can be deleted, or a whole new feature can appear. When those changes are of great evolutionary significance, they are thought of as an evolutionary innovation, as in the origin of hair in mammals or feathers in dinosaurs. Among the different kinds of deviations from recapitulation are heterochrony_changes in timing — and heterotopy_changes in spatial position in a structure. Modified from SánchezVillagra (2012), based on Wägele (2005)

the hypothetical recapitulatory pattern occur, as Haeckel (1866: p. 300) himself recognized. Features in a developmental sequence of new emerging events can move around or develop at different speeds, one or more of them can be omitted, or a whole new feature can appear. There are different kinds of developmental repatterning (Arthur 2011), and the organogenesis in the exercise and video presented here serve as general introduction to them. The comparisons among embryos of different species serve to explain patterns that suggest heterochrony, heterotopy, and heterometry, some of which foreshadow differences in adult body form (Richardson et al. 1997).

Comparisons reveal that the limbs are at different stages of development in relation to other structures, highlighting changes in relative timing (Richardson et al. 2009). For example, the forelimbs in marsupials are welladvanced in comparison with many other features, in contrast to any of the other vertebrates (Bininda-Emonds et al. 2007). This is because they have to climb up the fur of the mother to reach her teats short after birth (Werneburg and Spiekman in press).
In amniotes the head is large and distinctly marked off from the trunk, and the heart and the liver form a large bulge and develop early (Richardson et al. 1997). In fishes generally (e.g., zebrafish: Richardson et al. 1997) the heart has not yet formed at stages in which in amniotes the heart has complete looping (Jeffery et al. 2002). This reflects the higher complexity of the amniote heart, which needs more time to differentiate and hence starts to develop earlier (Starck 1979-1982).

There is a clear and simple relation that can be found between some patterns of organogenesis and adult form, related to body elongation and reduction of limbs. In many vertebrates body elongation is accompanied with a larger number of body segments and a reduction of limbs (Müller et al. 2010; Pough et al. 2012; Head and Polly 2015). Among the embryos, one can notice an inverse relationship between somite number and limb bud size (Richardson 1999; Keyte and Smith 2012).

In general, the earlier a structure appears in organogenesis, the larger its size or the greater its complexity in adults, because it has more time to develop (Werneburg 


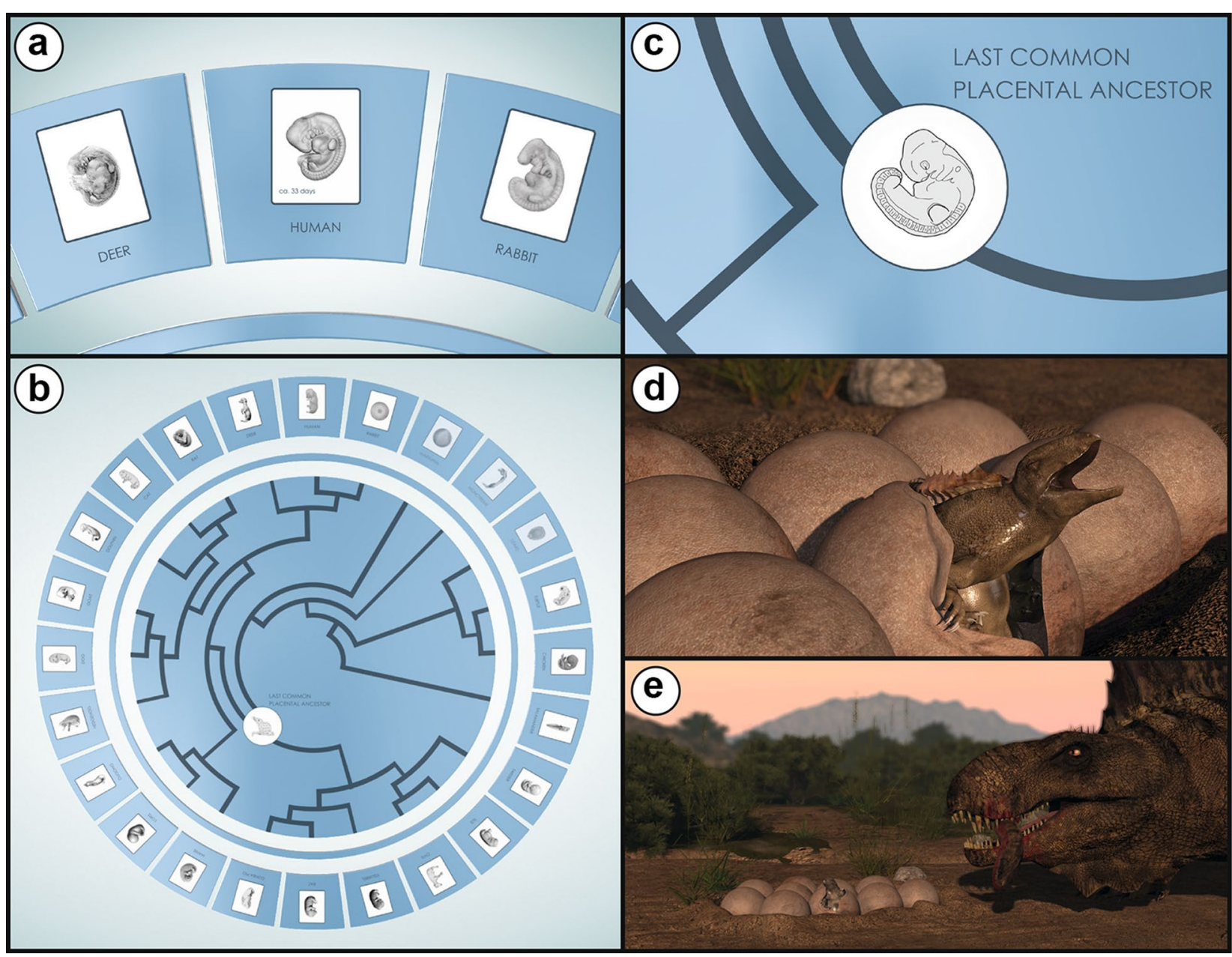

Fig. 5 Snapshots of the video on mammalian organogenesis, available in Supplement 3-10 (eight different languages) of this paper and under following link: https://www.youtube.com/user/SULACOgraphics. a Embryos of three placental mammal species, including humans, are compared in their development. $\mathbf{b}$ The phylogenetic arrangement of the depicted species follows Meredith et al. (2011) with modifications following references in Koyabu et al. (2014). c The reconstructed embryogenesis of the last common placental ancestor (Werneburg et al. 2016). d Animation of the hatching of an early amniote, illustrated for Dimetrodon (Synapsida, Permian) as example, with e an adult providing food, illustrating parental care

et al. 2015). Compared to other mammals, jaw characters in humans occur later, coupled with the fact that our "snouts" are very short compared to other species. The early developmental appearance of our limb related characters corresponds with our elongated limbs as adults.

\section{A video on comparative organogenesis in mammalian evolution}

The video, accompanied by a basic audio explanation, portrays prenatal transformations of individuals of different species, embedded in a tree of phylogenetic relationships (Fig. 5). For each species, simple drawings of embryos at different stages were integrated into an animation of transformation. As such, at once, an evolutionary tree depicts not just adults but ontogenies of species. The history of life is a history of life histories.

The video first shows the human, rabbit, and deer. The close-up of these three species first familiarizes the viewer with the embryos and makes obvious that there are similarities and differences among them. Each film represents a portion of a process that starts with the fertilized egg and progresses to the completed organogenesis; the animations of transformations (see also Additional files $11,12,13,14,15,16,17)$ illustrate that embryonic development does not occur in steps or stages, as unavoidably represented on the normal plates, but in a continuous transformation. 
Then the tree is shown, in which 21 other species are depicted in their relationships. The study of all these species using parsimony methods serve for the reconstruction of the organogenesis in the last common ancestor of placental mammals (Werneburg et al. 2016). There is then another close-up, that of outgroup representatives, namely a marsupial, a monotreme, and a lizard. Those species are necessary to root the placental tree and to reconstruct the ancestral sequence of character development.

\section{Discussion}

The exercise presented here explicitly and implicitly treats different subjects that are fundamental for teaching evolution, tree thinking, and evolutionary mechanisms. In what follows, we discuss some of these subjects and summarize current knowledge on central aspects of mammalian developmental evolution that could be integrated in the teaching on this subject.

Tree thinking. There are many aspects to public communication about evolution, but a fundamental one that would substantially help to correct misconceptions is to associate evolution with evolutionary trees. The presentation of tree-like patterns to depict genealogical relationships among species corrects misconceptions of evolution (Kutschera 2009; MacFadden et al. 2012; Scheyer et al. 2015) and even serves to increase the acceptance of evolution at the university level, according to a study on a population of US American college students (Walter et al. 2013). To provide an effective understanding involves demonstrating macroevolutionary patterns of evolutionary change, as it is the major transitions over long evolutionary time, such as the emergence of limbs in land vertebrates (Laurin 2010), the turtle shell (Scheyer et al. 2013), or the origin of whales (Thewissen 2014), that the layman wishes to understand (Padian 2010; Sánchez-Villagra 2012; Maier and Werneburg 2014).

The general public commonly and wrongly perceives evolution as representing improvement, being progressive and deterministic (discussed by Gould 2002; Zachos 2016). This misconception even reaches the language used by scholars and professional communication on evolution: Rigato and Minelli (2013) studied thousands of publications in the most renowned journals and found in them hundreds of cases of terms and expressions in agreement with the pre-evolutionary metaphor of the scala naturae or the great chain of being [discussed by (Lovejoy 1936; Rieppel 1989)], as when contrasting 'lower' to 'higher' representatives of a given branch of the tree of life. There is much evidence that even professional biologists lack a true understanding of phylogenetic trees (Morrison 2013). The 'classic' linear progression of the ape into the erected human is the most common image to be retrieved in searches for 'evolution' on the world wide web. This image is wrong, as the chimpanzees and humans have a common ancestor and both of them have a common ancestor with gorillas and all of them with the orangutan. All apes (incl. humans) are descendants of their last common ancestor.

Divorcing the pattern of common descent from mechanisms and emphasis on macroevolution. The exercise and the video presented here deal with the patterns of morphological changes in development. Leaving aside the mechanisms behind these patterns has many advantages. First of all, it divorces the pattern of common descent from what is generally understood as central to evolution, namely natural selection. The theory of evolution has experienced a significant conceptual and methodological expansion much beyond the Darwin-Wallace theory of natural selection (Gould 2002; Schmid and Bechly 2009; Zrzavý et al. 2013; Laland et al. 2014), yet allusions to the 'survival of the fittest' as the sole or most important component in it are rife (Safina 2010). In many texts, evolution is wrongly called 'Darwinism' (Scott and Branch 2009), raising an association with 'social Darwinism' and the rejection it provokes.

A second positive aspect of the exercise and the video presented here is the macroevolutionary perspective, concerning the large patterns and processes of differentiation at the level of species and above. As convincingly argued by Padian (2010), this aspect in education in evolutionary biology is largely neglected although an understanding of the major evolutionary transitions in the history of life would greatly contribute to diminish uncertainty about evolution (Maier and Werneburg 2014).

Integrating traditional embryology with modern analytical techniques and concepts and a comprehensive study of comparative organogenesis in mammals. The exposure to older works in comparative embryology provides the student with an appreciation of past works that involved careful anatomical documentation. The preponderance of older literature when revising the existing descriptions of development of vertebrates may give the impression that this is an outdated kind of research. This is not the case. Many works have emphasized the necessity to use comparative and quantitative approaches to document the evolution of the phenotype in parallel to experimental and genomic studies, and for that the expansion of the set of model species for developmental studies is fundamental (Jenner and Wills 2007; Milinkovitch and Tzika 2007). Among the recent descriptions of staging systems or developmental series in mammals are those of some bats (Cretekos et al. 2005; Tokita 2006; Wang et al. 2010), tenrecs (Werneburg et al. 2013a), and the echidna (Werneburg and Sánchez-Villagra 2011). These studies have been stimulated not only by the experimental approaches to understand evolutionary novelties arising 
in development and involving molecular biology (e.g., Sears 2011; Tokita et al. 2012; Montandon et al. 2014). The establishment of quantitative methods to compare developmental timing among species (e.g., Smith 2001; Germain and Laurin 2009; Maxwell and Harrison 2009; Goswami et al. 2016) has also stimulated analyses of accumulated knowledge, revisions of the anatomy of model species previously undocumented (Hautier et al. 2013; Werneburg et al. 2013b), and new studies on the comparative embryology and perinatal life of mammals (Bininda-Emonds et al. 2003), as in our research which was the basis of the animation presented here (Werneburg et al. 2016).

In Werneburg et al. (2016), we integrated information on organogenesis for two monotreme, ten marsupial, 66 placental species (five atlantogenatans and 61 boreoeutherians) and six sauropsids and a lissamphibian. Based on the 'standard event system' (SES) of Werneburg (2009), we documented the timing of 123 developmental events, and reconstructed using phylogenetic methods the developmental sequence and timing of organogenesis events in the last common ancestor of placental mammals. The main conclusions of that work are summarized as follows.

There is a mosaic-like pattern of life history traits throughout mammalian evolution. Viviparity evolved in the last common ancestor of marsupials and placentals, the last common ancestor of Theria (marsupials + placentals). The therian ancestor was intermediate between marsupials and placentals concerning altriciality, but the newborn resembled more the ancestral placental anatomy than the marsupial one. Mammals feature diverse levels of maturity at birth, ranging from altriciality to precocity. As is well known, in marsupials the hind limbs are less developed at birth and the forelimbs, used for climbing up the fur of the mother in order to reach the teats (Tyndale-Biscoe 2005), are well-formed. Compared to the therian condition, marsupial gestation length was reduced. The perinatal anatomy of the last common ancestor of placentals differs from that of marsupials. The placental newborn was probably altricial; it probably had closed eyes and an almost naked skin and its limbs were evenly developed. We reconstructed a litter of four young. The developmental innovations in placental mammals include a relatively shorter time until eyelid opening after birth and a longer gestation (125 days) than in the last therian common ancestor.

On the fossil record. The macroevolutionary perspective presented here poses the question on what role paleontology can play in developmental evolution of mammals (Pieretti et al. 2015). The evolutionary history of the synapsid lineage since the divergence from the sauropsid (reptiles and birds) sister-group in the Carboniferous
(Benton et al. 2015) is documented by a growing fossil record that documents the tempo and mode of acquisition of the many diagnostic features of Mammalia (Angielczyk 2009). The fossil record also documents features that reveal changes in growth patterns and markers of life history such as dental replacement (Sánchez-Villagra 2010; O'Meara and Asher 2016), but the direct record of organogenesis is almost non-existent (Franzen et al. 2015). As such, the fossil record is mute on the subject treated here, but it does provide the evolutionary time in which the groups in question diverged.

\section{Conclusions}

The proposed activity addresses the evidence-based process of science among the core competencies of the Vision and Change report on education in undergraduate biology (Brewer and Smith 2011). The developmental patterning of the 'body plan' of animals is determined by complex and multi-genic interactions (Held Jr. 2014). The role of Hox genes and other genes in this process is usually the subject of courses, whereas the phenotypic transformations that occur in the individual development and the changes on such transformations in geological time are in many cases neglected. The activity presented here serves to address this deficit with an effective exercise that combines concepts of development and evolution. The use of a developmental perspective can bring great insights into teaching human anatomy even from a clinical perspective (Diogo et al. 2016).

\section{Additional files} Additional file 1. Figures of normal tables of species listed in Table 1 and
Fig. 3.

Additional file 2. Power Point file with the Figures of the article.

Additional file 3. Animation (English version). The first part shows the simplified scheme of the phylogenetic framework used here.Images of embryos and fetuses are taken from different sources. Drawings of ancestral placental embryos are based on the reconstruction of the ancestral sequence the embryological characters studied herein. Part 2 presents a life reconstruction of ten eggs (as reconstructed herein) and one hatchling with its mother of the early amniote Dimetrodon (Synapsida). A focus is laid on the reconstructed closed eyelids at hatching. Below the text spoken during the animation (speaker: Laura A. B. Wilson). The evolution of organogenesis in mammals. Extant mammals show a great diversity in body form: humans and dolphins, dogs and bats, elephants and mice. At birth they already resemble the anatomy of their adults. The characteristic shape at birth is established in prenatal life, long before birth. Although a human newborn is very different from an adult, a human can be distinguished from its closest evolutionary relatives already at birth. Using an evolutionary framework illustrating the tree of mammalian life it is possible to compare the development of the organs and general anatomy of a variety of mammalian species. Here we see embryos of deer, human and rabbit as examples of placental mammals. We documented the order of appearance of discrete embryological features belonging to the limbs - arms and legs-, heart, eye, ear, and snout development, as well as somites and branchial arches. A change in the timing of those characters — earlier or later appearance-results 
in larger or smaller organs. A specific sequence of events characterizes species. As development progresses, the differences among deer, human, and rabbit appear. The comparison can be extended to many more mammalian species...... and with all the information we can reconstruct the organogenesis of the last common ancestor of all placental mammals. We answer the question: how did the first placentals, which probably lived around the time of non-avian dinosaurs, develop in the uterus? It was likely born after four months and weaning took place after several weeks. We can then make comparisons with other mammalian and with reptilian species to better understand what makes placentals unique. For marsupials, for monotremes (which include platypus and echidna), and reptiles we reconstructed the ancestral organogenesis. We found that several fully terrestrial land vertebrates open their eye lids long after birth or hatching, which shows that the young are blind for a long time and need help to survive. Based on those findings, we reconstructed the life history of the last common ancestor of all fully land adapted vertebrates, the amniotes. We hypothesized based on comparisons among species that that animal laid 10 eggs. We found that the hatchling had closed eyes, like most mammals at birth, and the eyelids opened after $18^{*}$ days. In this long period, the young was blind and the mother must have fed and protected the young. *Corrected compared to the audio version.

Additional file 4. Animation (German version). See caption of Additional file 3 for overview. Below the text spoken during the animation (translator and speaker: Ingmar Werneburg). Die Evolution der

Organbildung bei Säugetieren. Die heutigen Säugetiere weisen eine große Vielfalt in ihren Körperformen auf: Menschen und Delphine, Hunde und Fledermäuse, Elephanten und Mäuse. Bei ihrer Geburt spiegeln sie bereits die Anatomie der Erwachsenen wider. Die charakteristische Körperform wird lange vor der Geburt im Embryo ausgebildet. Obwohl ein neugeborener Mensch sich sehr von einem Erwachsenen unterscheidet, so kann dieser jedoch bei Geburt klar von den nächstverwandten Arten unterschieden werden. Mit einem evolutionären Ansatz, bei dem der Stammbaum der Säugetiere genutzt wird, ist es möglich, die Entwicklung verschiedener Organe und die generelle Anatomie bei einer Vielzahl verschiedener Säugetierarten zu vergleichen. Hier kann man die frühe Entwicklung von Rehen, Menschen und Kaninchen, als Vertreter der Plazenta-Säugetiere, beobachten. In unserer Studie haben wir für jede Tierart die zeitliche Sequenz für das Erscheinen diskreter Embryonalmerkmale dokumentiert. Zu diesen Merkmalen zählen die Gliedmaßen - Arme und Beine -, das Herz, Auge, Ohr und die Schnauzenentwicklung, aber auch Somiten und Kiemenbögen. Eine Veränderung im zeitlichen Auftreten dieser Merkmale - ein früheres oder späteres Erscheinen - resultiert in größeren oder kleineren Organen. Jede Tierart ist durch eine ganz eigene Embryonalsequenz charakterisiert. Bei fortschreitender Entwicklung nehmen die Unterschiede zwischen Rehen, Menschen und Kaninchen zu. Der Vergleich wurde auf viele weitere Säugetierarten ausgeweitet und mit den ganzen Informationen kann man die Organentwicklung des letzten gemeinsamen Vorfahrens aller plazentalen Säugetiere rekonstruieren. Wir geben Antwort auf die Frage, wie sich die ersten Plazenta-Tiere in der Gebärmutter entwickelt haben - und das in einer Zeit, als die Dinosaurier noch die Erde beherrschten. Das früheste plazentale Säugetier wurde wahrscheinlich nach vier Monaten Tragzeit geboren und bis zur Entwöhnung vergingen mehrere Wochen. Wir haben dann weitere Vergleiche mit anderen Säugetieren und Reptilien durchgeführt, um herauszufinden, was die Plazenta-Tiere so besonders macht. Wir rekonstruierten die ursprüngliche Organsequenz bei Beuteltieren, Kloakentieren und Reptilien. Dabei stellte sich heraus, daß zahlreiche voll terrestrische Wirbeltiere ihre Augenlider erst nach der Geburt oder nach dem Schlüpfen öffnen. Dies zeigt, daß die Jungen zunächst blind sind und Hilfe brauchen, um zu überleben. Auf Grundlage dieser Entdeckungen rekonstruierten wir die frühe Lebensgeschichte des letzten gemeinsamen Vorfahrens aller völlig ans Land angepaßter Landwirbeltiere, der Amnioten. Basierend auf den durchgeführten Vergleichen stellten wir die Hypothese auf, daß dieses Tier zehn Eier gelegt hatte. Der Schlüpfling hatte geschlossene Augen, wie die meisten Säugetiere bei ihrer Geburt, und die Augenlider öffneten sich erst nach $18^{*}$ Tagen. Während dieser langen Zeit war das Junge blind und mußte von der Mutter gefüttert und beschützt werden. ${ }^{*}$ Corrected compared to the audio version.
Additional file 5. Animation (Spanish version). See caption of Additional file 3 for overview. Below the text spoken during the animation (translator and speaker: Marcelo R. Sánchez-Villagra). La evolución de la organogénesis en mamíferos. Los mamíferos actuales muestran una gran diversidad: humanos y delfines, perros y murciélagos, elefantes y ratones. La forma característica que tienen al nacer se establece durante el desarrollo prenatal, antes del nacimiento. Aunque un humano recién nacido es muy diferente a un adulto, un ser humano puede ser distinguido fácilmente de su pariente evolutivo más cercano, el chimpancé. Utilizando un marco evolutivo, es decir el árbol de la vida de los mamíferos, estudiamos el desarrollo de los órganos y la anatomía general de una variedad de especies de mamíferos. Aquí vemos embriones de ciervo, humano y conejo como ejemplo de mamíferos placentarios. Documentamos la secuencia y tiempo de aparición de 123 características embriológicas discretas, pertenecientes al desarrollo de los brazos y piernas, corazón, ojos, orejas y hocico. Un cambio en el tiempo de aparición de éstas características resulta en órganos más grandes o más pequeños. La combinación específica de la secuencia de eventos caracteriza las especies. De esta manera las diferencias entre ciervos, humanos, y conejos van formándose durante el desarrollo embrionario. Un estudio de este tipo incluyó 77 especies de mamíferos y con esa información reconstruimos la organogénesis del ancestro común de todos los mamíferos placentarios. Nuestra pregunta era: ¿cómo era el desarrollo en el útero del primer mamífero placentario, que vivió alrededor del tiempo de la desaparición de los dinosaurios?El primer mamífero placentario tenía un tiempo de gestación de casi cuatro meses y el destete ocurría luego de unos tres meses. A continuación, hicimos comparaciones con especies distintas a las de los mamíferos, para comprender mejor que es lo que hace únicos a los placentarios. Documentamos también la secuencia y momento de aparición de los eventos del desarrollo y reconstruímos la organogénesis ancestral para marsupiales, monotremas y reptiles. Encontramos que varios vertebrados completamente terrestres abren sus párpados mucho después de nacer o de salir del cascarón, lo cual muestra que las crías permanecen ciegas por mucho tiempo y necesitan ayuda para sobrevivir. Con base en estos descubrimientos, reconstruimos la historia de vida del ancestro común de todos los vertebrados completamente adaptados a la vida terrestre, los amniotas. Reconstruimos 10 huevos para el amniota ancestral y hallamos que la cría recién eclosionada tenía los ojos cerrados, como la mayoría de los mamíferos al nacer, y que los párpados se abrían después de 18 días. Durante este largo tiempo, la cría permanecía ciega y la madre debió haber alimentado y protegido la cría.

\section{Additional file 6. Animation (Italian version). See caption of} Additional file 3 for overview. Below the text spoken during the animation (translator: Massimo Delfino, speaker: Liana Marino). L'evoluzione dell'organogenesi nei mammiferi. I mammiferi attuali mostrano una grande diversità in termini di forma corporea: esseri umani e delfini, cani e pipistrelli, elefanti e topi. La forma che li caratterizza quando nascono è stabilita nella vita prenatale, molto prima della nascita. Sebbene un essere umano neonato sia molto diverso da un adulto, è possibile distinguerlo dai suoi parenti evolutivi più stretti già alla nascita. I neonati hanno una anatomia chiaramente riconducibile a quella degli adulti della loro specie. All'interno di un contesto evolutivo, l'albero filogenetico dei mammiferi, abbiamo studiato lo sviluppo degli organi e dell'anatomia generale di numerose specie. Qui vediamo gli embrioni di cervo, uomo e coniglio come esempi di mammiferi placentati. Abbiamo documentato l'ordine di comparsa di 123 caratteri embriologici discreti che riguardano lo sviluppo di arti, cuore, occhio, orecchio e muso. Un cambiamento nella tempistica dello sviluppo di questi caratteri -una comparsa anticipata o ritardata- ha come risultato il generarsi di organi più grandi o più piccoli. Ogni specie è caratterizzata da una precisa sequenza di eventi. Con il progredire dello sviluppo, compaiono le differenze fra il cervo, l'uomo e il coniglio. Questo studio è stato esteso a 77 specie di mammiferi e, grazie alle informazioni raccolte, abbiamo ricostruito l'organogenesi dell'ultimo antenato comune di tutti i mammiferi placentati. Abbiamo risposto alla domanda: come si è sviluppato nell'utero il primo placentato, che probabilmente è vissuto al tempo in cui i dinosauri sono scomparsi? Nasceva dopo quasi 4 mesi e lo svezzamento richiedeva altrettanto tempo. Quindi abbiamo effettuato dei confronti con specie non appartenenti al gruppo dei mammiferi per capire cosa rende unici i placentati. Abbiamo anche documentato la 
tempistica dello sviluppo di 123 caratteri embriologici dei marsupiali, dei monotremi (che includono l'ornitorinco e l'echidna), e dei rettili. Grazie a queste informazioni abbiamo ricostruito l'organogenesi ancestrale. Abbiamo scoperto che molti vertebrati terrestri aprono le palpebre molto dopo la nascita o la schiusa e questo indica che i giovani sono ciechi per un lungo periodo e hanno bisogno di aiuto per sopravvivereSulla base di questi risultati, abbiamo ricostruito la life history dell'ultimo antenato comune di tutti i vertebrati completamente adattati alla vita sulla terraferma, gli amnioti. Grazie al confronto fra specie, abbiamo ipotizzato che quell'animale deponesse 10 uova, che il neonato avesse gli occhi chiusi (come la maggior parte dei mammiferi alla nascita) e che le palpebre si aprissero dopo $18^{*}$ giorni. Durante tutto questo lungo periodo, il neonato era cieco e doveva essere alimentato e protetto dalla madre. ${ }^{*}$ Corrected compared to the audio version.

Additional file 7. Animation (French version). See caption of Additional file 3 for overview. Below the text spoken during the animation (translator and speaker: Eli Amson). L'évolution de l'organogenèse chez les mammifères. Les mammifères actuels sont caractérisés par une grande diversité de formes corporelles : humains et dauphins, chiens et chauves-souris, éléphants et souris. A la naissance, l'anatomie de l'adulte est déjà perceptible. The forme caractéristique à la naissance est établie durant la vie prénatale, bien avant la naissance. Bien que le nouveau né humain soit très différent de l'adulte, un humain peut être distingué de son plus proche parent dès la naissance. A l'aide d'un cadre phylogénétique, c'est à dire l'arbre des relations de parentés des mammifères, nous avons étudié le développement des organes et l'anatomie générale chez de nombreuses espèces de mammifères. Nous pouvons voir ici des embryons d'un cerf, d'un humain et d'un lapin, tous trois des mammifères placentaires. Nous avons déterminé l'ordre d'apparition de 123 caractères embryologiques discrets qui concernent le développement des membres antérieurs et postérieurs, du cœur, des yeux, des oreilles et du museau. Une modification dans l'ordre d'apparition des ces caractères - une apparition précoce ou retardée, implique des organes plus grands ou plus petits. Une combinaison spécifique de cette séquence d'évènements caractérise chaque espèce et les différences entre cerf, humain et lapin apparaissent au cours du développement. Ce genre d'étude a été étendue à 77 espèces de mammifères...et c'est grâce à ces données que nous avons put reconstruire l'organogenèse de l'ancêtre commun à tous les placentaires. Nous avons donc pu répondre à la question suivante : comment le premier mammifère placentaire, qui a probablement vécu de l'époque de la disparition des dinosaures non-aviens, s'est développé au sein de l'utérus ? La naissance eu lieu après presque 4 mois de gestation, après quoi et une période de durée similaire fût nécessaire avant le sevrage. Nous avons alors comparer cela à des espèces non-mammalienne, pour mieux comprendre ce qui rend Les mammifères placentaires uniques. Nous avons donc également déterminé l'ordre d'apparition des 123 caractères développementaux chez les marsupiaux, l'ornithorynque, l'échidné et les reptiles, et reconstruit l'organogenèse ancestrale. Nous avons trouvé que plusieurs vertébrés terrestres ouvrent les yeux bien après la naissance, ce qui indique que le petit est aveugle durant une longue période et requiert de l'aide pour survivre. En se fondant sur ces découvertes, nous avons reconstruit le cycle de vie de l'ancêtre commun à tous les vertébrés terrestres, les amniotes. Nous avons estimé que la ponte de l'ancêtre des amniotes comprenait 10 œufs, et avons trouvé que le nouveau-né avait les paupières soudées, comme la plupart des mammifères à la naissance, et que les yeux s'ouvraient après $18^{*}$ jours. Durant cette longue période, le petit était aveugle, et avait besoin que sa mère lui fournisse nourriture et protection. *Corrected compared to the audio version.

Additional file 8. Animation (Russian version). See caption of Additional file 3 for overview. Below the text spoken during the animation (translator and speaker: Oleksandr Yaryhin). Эволюция органогенеза млекопитающих. Современные млекопитающие обладают огромным разнообразием формы тела: человек и дельфин, собака и летучая мышь, слон и мышь. Уже при рождении форма их тела соответствует форме взрослых. Становление характерной формы тела при рождении происходит еще в пренатальном периоде, задолго до появления на свет. Несмотря на то, что новорожденный очень отличается от взрослого человек, новорожденного человека можно отличить от его ближайших эволюционных родственников. Используя эволюционную основу, иллюстрирующую древо жизни млекопитающих можно сравнить развитие органов и общей анатомии различных видов млекопитающихЗдесь мы можем увидеть эмбрионы оленя, человека и кролика, как примеры плацентарных животных. Мы задокументировали оередность появления отдельных эмбриональных принаков относящихся к конечностям - руки и ноги-, сердце, глаз, ухо, развитие передней части головы (рыла), а также сомитов и жаберных дуг. Изменение времени появления этих признаков - ранее или позднее - зависит от размеров самого органа. Специфическая последовательность событий характеризует виды. В процессе развития проявляются отличия между оленем, человеком и кроликом. Сравнение можно расширить к гораздо большему числу млекопитающих...... и со всеми этими данными мы можем воссоздать органогенез последнего общего предка всех плацентарных животных. Мы отвечаем на вопрос: как происходило внутриутробное развитие первых плацентарных, возможно живших еще во времена нептичьих динозавров. Это животное скорее всего роджалось после 4 месяцев внутриутробного развития и прекращение кормления грудным молоком происходило через несколько недель. Что бы лучше понять, что делает плацентарных такими уникальными мы проведем сравнение с другими видами млекопитающих и рептилий. Мы реконструировали предковый органогенез для сумчатых, однопроходных и рептилий. Мы выяснили, что некоторые полностью назумные позвоночные открывают веки намного позже рождения или вылупления, это говорит о том, что маленькие остаются слепыми длительное веремя и для того что бы выжить нуждаются в защите. Основываясь на этих данных, мы реконструировали жизненный цикл последнего общего предка полностью наземных позвоночных - амниот. Основываясь на сравнении между видами, мы выдвинули гипотезу, что это животное откладывало 10 яиц. Мы выяснили, что у новорожденного были закрытые глаза, как у большинства млекопитающих при рождении, а веки открывались на $18^{*}$-й день жизни. На протяжении длительного периода, молодая особь была слепой и ее мать должна была ее кормить и защищать. *Corrected compared to the audio version.

Additional file 9. Animation (Japanese version). See caption of Additional file 3 for overview. Below the text spoken during the animation (translator and speaker: Daisuke Koyabu). 哺乳類の器官形成の進化こ んにち地球に生きる哺乳類の身体には驚くべき多様性がありま す。ヒト、イルカ、イヌ、コウモリ、ゾウ、ネズミ。彼らはうま れてくる時点で既にオトナと似た体をもってうまれてきます。種 を特徵づける形状は出生が起きるずっと前の胎児期には既に完成 しています。ヒトの新生児はオトナとは見た目が少し違うもの の、ヒトに最も近い動物であるチンパンジーなどとははっきり区 別することができます。近年明らかになってきた哺乳類の系統関 係をもとに、哺乳類の器官形成と形態を種間で比べることが可能 になってきました。これらはシカ、ヒト、ウサギの胎児の例で す。私達のグループは手足、心臟、眼球、耳、鼻、体節、咽頭弓 などの重要な身体パーツが形成される順序を様々な哺乳類で調べ ました。その結果、身体パーッの形成のタイミングが変わること で、その器官の相対的なサイズが変化することがわかりました。 それぞれの種を特徵づけるょうな身体パーッの形成の順序がある わけです。発生が進むにつれてシカやヒト、ウサギの身体の違い がはっきりしてゆきます。このような比較を様々な種の有胎盤類 哺乳類で行いました。そして、全ての有胎盤類の共通祖先の器官 形成を理論的に推定することができました。では恐竜と同じ時代 を生きたであろう、初めての有胎盤類はどのように成長をしたの でしょう?恐らく、おおよそ4r月の妊娠期間があり、生後数週間 で離乳が起きたと考えられます。私たちはさらに有袋類や単孔類 といったその他の哺乳類や爬虫類を調べ、有胎盤類の独自性の解 析を進めました。有袋類と単孔類、そして爬虫類の祖先の器官形 成を同じく復元しました。いくつかの陸棲脊椎動物では稃化ある いは出生よりずっと後に瞼が開くことがわかりました。これは、 新生児は長い間眼が見えず、親の保護が必要であることを意味し ます。私たちは収集してきたデータを統合し、陸棲脊椎動物全 ての共通祖先である、初めての羊膜類の生活史の復元を試みま した。初めての羊膜類は10個程の卵を産んでいたと考えられま す。そして、新生児は多くの哺乳類のょうに瞼が閉じたまま産ま 
れ、出生後 $18 *$ 日目で初めて眼が開いたと考えられます。新生児 はその間眼が見えず、母親による保護を受けていたと考えられま す。 ${ }^{*}$ Corrected compared to the audio version.

Additional file 10. Animation (Chinese version). See caption of Additional file 3 for overview. Below the text spoken during the animation (translator and speaker: Lijuan Cheng). 哺乳动物器官形成的进化 现存 的哺乳动物展现着各式各样的身体形式: 人, 海豚, 狗, 蝙蝠, 大象, 老 鼠。从出生开始他们已经拥有和成年时期相似的解剖结构。他们特 定的形态是在出生很久以前的胎儿期就已经形成的。虽然人类新生 儿和成年是有很大差别的, 从一出生人类就已经和与它最近的进化 亲属区别开来。用一个进化框架阐明哺乳动物的生命之树, 可以比较 多种哺乳动物器官发育和一般的解剖结构。在这里我们把鹿, 人类和 兔子的胚胎作为胎盘哺乳动物的例子。我们记录了不连续的胚胎功 能出现的顺序, 包括四肢一胳膊和腿 - , 心脏, 眼睛, 耳朵, 鼻子的发 育, 以及体节和鳃弓的发育。这些特征形成时间的变化 - 较早或较 晚的出现一导致更大或更小的器官。发育的特定顺序使物种具有各 自的特征。在发育过程中, 鹿, 人类, 兔子之间的差异逐渐出现。该比 较可以扩展到更多的哺乳动物物种………… . 基于这些信息, 我们 可以重建所有胎盘哺乳动物的最后共同祖先的器官形成。我们回答 这个问题:第一个可能生活在大约非鸟类恐龙时代的胎盘哺乳动物是 如何在子宫中发育的呢?它可能是在四个月后出生的, 数周后断奶。 然后我们可以比较其他哺乳动物和爬行动物物种, 更好地理解是什么 使胎盘哺乳动物与众不同。对于有袋动物, 单孔目动物 (包括鸭嘴兽 和针鼣), 和爬行动物我们重建祖先的器官发生。我们发现, 一些完全 陆生脊椎动物在它们出生或孵化很久后才睁开眼皮, 这表明幼息在很 长一段时间里是看不见的, 并需要帮助才能生存。基于这些发现, 我 们重建了完全适应陆地生活的脊椎动物的最后共同祖先的生活史, 羊 膜动物。根据不同物种间的比较我们假设这个动物下 10 个蛋。我们 发现刚捊化的幼体是闭眼的, 像刚出生大多数哺乳动物一样, 眼睑在 $18 *$ 天后打开。在这一长段时间段里, 幼体是看不见的, 它们的母亲必 须哺育并且保护它们。 ${ }^{*}$ Corrected compared to the audio version.

Additional file 11. Reconstructed organogenetic transformation of the lizard, Lacerta agilis (Peter 1904) as shown in the animation.

Additional file 12. Reconstructed organogenetic transformation of the last common ancestor of placental mammals (Werneburg and Spiekman in press) as shown in the animation.

Additional file 13. Reconstructed organogenetic transformation of the echidna, Tachyglossus aculeatus (Semon 1894) as shown in the animation.

Additional file 14. Reconstructed organogenetic transformation of the marsupial "eastern quoll", Dasyurus viverrinus (Werneburg and Spiekman in press) as shown in the animation.

Additional file 15. Reconstructed organogenetic transformation (morph) of the roe deer, Capreolus capreolus (Sakurai 1906) as shown in the animation

Additional file 16. Reconstructed organogenetic transformation of the rabbit, Oryctolagus cuniculus (Minot and Taylor 1905) as shown in the animation.

Additional file 17. Reconstructed organogenetic transformation of the human, Homo sapiens (Keibel and Elze 1908) as shown in the animation.

Additional file 18. Glossary.

\section{Authors' contributions}

Both authors contributed equally to all steps in the project and manuscript preparation. Both authors read and approved the final manuscript.

\footnotetext{
Author details

1 Paläontologisches Institut und Museum der Universität Zürich, Karl Schmid Strasse 4, 8006 Zürich, Switzerland. ${ }^{2}$ Senckenberg Center for Human Evolution and Palaeoenvironment (HEP) at Eberhard Karls Universität, Sigwartstr. 10, 72074 Tübingen, Germany. ${ }^{3}$ Fachbereich Geowissenschaften, Eberhard Karls Universität, Hölderlinstraße 12, 72076 Tübingen, Germany. ${ }^{4}$ Museum für Naturkunde, Leibniz-Institut für Evolutions- and Biodiversitätsforschung an der Humboldt-Universität zu Berlin, Invalidenstraße 43, 10115 Berlin, Germany.
}

\section{Acknowledgements}

We thank Catalina Pimiento (Zürich) for discussions, Alexandra Wegmann (Zürich) and Agnes Fatz (Tübingen) for technical assistance, Frank Zachos (Vienna) and an anonymous reviewer for useful suggestions for improvements and Thure Kjer (http://www.sulaco-graphics.de) for preparing the animation. We also thank our dear colleagues who kindly provided the different language versions of the animation: Daisuke Koyabu (Tokyo), Liana Marino (Florence), Laura Wilson (Sydney), Oleksandr Yaryhin (Kiev), Lijuan Cheng (Tübingen) and Eli Amson (Berlin). We also thank Massimo Delfino (Turin) for his help.

\section{Competing interests}

The authors declare that they have no competing interests.

\section{Funding}

The study was funded by the SNF fund 31003A_149605 to M.R.S.-V and SNF fund P300PA_164720 to I.W.

Received: 9 July 2016 Accepted: 20 November 2016

Published online: 01 December 2016

\section{References}

Angielczyk KD. Dimetrodon is not a dinosaur: using tree thinking to understand the ancient relatives of mammals and their evolution. Evol Educ Outreach. 2009;2:257-71.

Arthur W. Evolution. A developmental approach. Hoboken: Wiley; 2011.

Asher RJ. Evolution and belief: confessions of a religious paleontologist. Cambridge: University Press; 2012.

Baum DA, Smith SD. Tree thinking: an introduction to phylogenetic biology. Greenwood Village: Roberts and Co; 2012

Benton MJ, Donoghue PCJ, Asher RJ, Friedman M, Near TJ, Vinther J. Constraints on the timescale of animal evolutionary history. Palaeontol Electron. 2015;18(1):1-106.

Bininda-Emonds ORP, Jeffery JE, Richardson MK. Is sequence heterochrony an important evolutionary mechanism in mammals? J Mamm Evol. 2003;10(4):335-61.

Bininda-Emonds ORP, Jeffery JE, Sánchez-Villagra MR, Hanken J, Colbert M, Pieau C, Selwood L, Cate C, Raynaud A, Osabutey CK. Forelimbhindlimb developmental timing changes across tetrapod phylogeny. BMC Evol Biol. 2007;7:1.

Brauer A. Beiträge zur Kenntnis der Entwicklung und Anatomie der Gymnophionen. II. Die Entwicklung der äussern Form. Zoologische Jahrbücher. Abteilung für Anatomie und Ontogenie der Tiere. 1899;12(3):477-508.

Brewer CA, Smith D, editors. Vision and change in undergraduate biology education: a call to action. Washington: American Association for the Advancement of Science; 2011.

Cooper K, Sears KE, Uygur A, Maier J, Stephan-Backowski K, Brosnahan M, Antczak D, Skidmore J, Tabin C. Patterning and post-patterning modes of evolutionary digit loss in mammals. Nature. 2014;511:41-5.

Cretekos CJ, Weatherbee SD, Chen CH, Badwaik NK, Niswander L, Behringer RR, Rasweiler JJIV. Embryonic staging system for the short-tailed fruit bat, Carollia perspicillata, a model organism for the mammalian order Chiroptera, based upon timed pregnancies in captive-bred animals. Dev Dyn. 2005;233:721-38.

Cubo J. Process heterochronies in endochondral ossification. J Theor Biol. 2000;205:343-53.

de Jong IML, Colbert MW. Witte F, Richardson MK. Polymorphism in developmental timing: intraspecific heterochrony in a Lake Victoria cichlid. Evol Dev. 2009;11:625-35.

Diogo R, Noden D, Smith CM, Molnar JA, Boughner J, Barrocas C, Bruno J. Learning and understanding human anatomy and pathology: an evolutionary and developmental guide for medical students. Oxford: Taylor \& Francis; 2016. p. 348

Ereshefsky M. Homology thinking. Biol Philos. 2012;27:382-400.

Eycleshymer AC, Wilson JM, editors. Normal plates of the development of Necturus maculosus (Vol. 11). Jena: Gustav Fischer Verlag; 1910

Franzen JL, Aurich C, Habersetzer J. Description of a well preserved fetus of the European Eocene Equoid Eurohippus messelensis. PLoS ONE. 2015;10(10):e0137985. 
Germain D, Laurin M. Evolution of ossification sequences in salamanders and urodele origins assessed through event-pairing and new methods. Evol Dev. 2009;11(2):170-90.

Gilbert SF. Developmental biology. Sunderland: Sinauer Associates; 2013.

Glaesner L. Normentafel zur Entwicklungsgeschichte des gemeinen Wassermolches (Molge vulgaris), vol. 14. Jena: Verlag von Gustav Fischer; 1925.

Goswami A, Randau M, Polly PD, Weisbecker V, Bennett CV, Hautier L, SánchezVillagra MR. Do developmental constraints and high integration limit the evolution of the marsupial oral apparatus? Integr Comp Biol. 2016;56:404-15.

Gould SJ. The structure of evolutionary theory. Cambridge: The Belknap Press of Harvard University Press; 2002.

Grosser O, Tandler J. Normentafel zur Entwicklungsgeschichte des Kiebitzes (Vanellus cristatus MEYER), vol. 9. Jena: Gustav Fischer Verlag; 1909.

Haeckel E. Generelle Morphologie der Organismen. Bd. 2: Allgemeine Entwicklungsgeschichte der Organismen. Berlin: Georg Reimer; 1866.

Hanken J. Is heterochrony still an effective paradigm for contemporary studies of evo-devo. In: Love AC, editor. Conceptual change in biology: scientific and philosophical perspectives on evolution and development. Boston studies in the philosophy and history of science. Berlin: Springer-Verlag; 2015. p. 97-110.

Harjunmaa E, Seidel K, Hakkinen T, Renvoise E, Corfe IJ, Kallonen A, Zhang ZQ Evans AR, Mikkola ML, Salazar-Ciudad I, Klein OD, Jernvall J. Replaying evolutionary transitions from the dental fossil record. Nature. 2014;512:44-8.

Hautier L, Bennett NC, Viljoen H, Howard L, Milinkovitch MC, Tzika AC, Goswami A, Asher RJ. Patterns of ossification in southern versus northern placental mammals. Evolution. 2013;67(7):1994-2010.

Head JJ, Polly PD. Evolution of the snake body form reveals homoplasy in amniote Hox gene function. Nature. 2015;520(7545):86-9.

Held LI Jr. How the snake lost its legs: curious tales from the frontier of evo devo. Cambridge: Cambridge University Press; 2014.

Henneberg B. Normentafel zur Entwicklungsgeschichte der Wanderratte (Rattus norvegicus Erxleben), vol. 15. Jena: Verlag von Gustav Fischer; 1937.

Hopwood N. Visual standards and disciplinary change: normal plates, tables and stages in embryology. Hist Sci. 2005:43:239-303.

Hopwood N. A history of normal plates, tables and stages in vertebrate embryology. Int J Dev Biol. 2007;51:1-26.

Hubrecht AAW, Keibel F. Normentafel zur Entwicklungsgeschichte des Kobold maki (Tarsius spectrum) und des Plumlori (Nycricebus tardigradus), vol. 7. Jena: Verlag von Gustav Fischer; 1907.

Jeffery JE, Bininda-Emonds ORP, Coates MI, Richardson MK. Analyzing evolutionary patterns in amniote embryonic development. Evol Dev. 2002;4(4):292-302.

Jenner RA, Wills MA. The choice of model organisms in evo-devo. Nat Rev Genet. 2007;8:311-9.

Keibel F. Normentafel zur Entwicklungsgeschichte des Schweines (Sus scrofa domesticus), vol. 1. Jena: Verlag von Gustav Fischer; 1897.

Keibel F, Abraham K. Normentafel zur Entwicklungsgeschichte des Huhnes (Gallus domesticus), vol. 2. Jena: Verlag von Gustav Fischer; 1900.

Keibel F, Elze C. Normentafel zur Entwicklungsgeschichte des Menschen, vol. 8. Jena: Verlag von Gustav Fischer; 1908.

Kerr JG. Normal plates of the development of Lepidosiren paradoxa and Protopterus annectens, vol. 10. Jena: Verlag von Gustav Fischer; 1909.

Keyte A, Smith KK. Heterochrony in somitogenesis rate in a model marsupial, Monodelphis domestica. Evol Dev. 2012;14(1):93-103.

Koyabu D, Werneburg I, Morimoto N, Zollikofer CPE, Forasiepi AM, Endo H, Kimura J, Ohdachi SD, Son NT, Sánchez-Villagra MR. Mammalian skull heterochrony reveals modular evolution and a link between cranial development and brain size. Nat Commun. 2014;5:3625.

Kutschera U. Tatsache evolution. München: Deutscher Taschenbuch Verlag; 2009.

Laland KN, Uller T, Feldman MW, Sterelny K, Müller GB, Moczek A, Jablonka E, Odling-Smee FJ. Does evolutionary theory need a rethink? Nature. 2014;514:161-4

Laurin M. How vertebrates left the water. Berkeley: University of California Press; 2010.

Lovejoy AO. The great chain of being: a study of the history of an idea. Cambridge: Harvard University Press; 1936.

MacFadden BJ, Oviedo LH, Seymour GM, Ellis S. Fossil horses, orthogenesis, and communicating evolution in museums. Evol Educ Outreach. 2012;5:29-37.
Macrini TE. Quantitative comparison of ontogenetic and phylogenetic character changes in the synapsid mandible and auditory region. J Mamm Evol. 2002;9(3):185-208.

Maier W. On the evolutionary biology of early mammals-with methodological remarks on the interaction between ontogenetic adaptation and phylogenetic transformation. Zoologischer Anzeiger. 999:238(1):55-74

Maier W, Werneburg I. Einführung: Zur Methodik der organismischen Evolutionsbiologie. In: Maier W, Werneburg I, editors. Schlüsselereignisse der organismischen Makroevolution (Vol. Zürich: Scidinge Hall Verlag; 2014 p. 11-7.

Martin T, Ruf I. On the mammalian ear. Science. 2009;326(5950):243-4.

Maxwell EE, Harrison LB. Methods for the analysis of developmental sequence data. Evol Dev. 2009;11(1):109-19.

Meredith RW, Janečka JE, Gatesy J, Ryder OA, Fisher CA, Teeling EC, Goodbla A, Eizirik E, Simão TLL, Stadler T, Rabosky DL, Honeycutt RL, Flynn JJ, Ingram CM, Steiner C, Williams TL, Robinson TJ, Burk-Herrick A, Westerman M, Ayoub NA, Springer MS, Murphy WJ. Impacts of the cretaceous terrestrial revolution and $\mathrm{KPg}$ extinction on mammal diversification. Science. 2011:334:521-4.

Milinkovitch MC, Tzika A. Escaping the mouse trap: the selection of new Evo-Devo model species. J Exp Zool Part B Mol Dev Evol. 2007:308(4):337-46.

Minot CS, Taylor E. Normal plates of the development of the rabbit (Lepus cuniculus L.), vol. 5. Jena: Gustav Fischer Verlag; 1905.

Montandon SA, Tzika AC, Martins A, Chopard B, Milinkovitch MC. Two waves of anisotropic growth generate enlarged follicles in the spiny mouse. EvoDevo. 2014;5(33):1-13.

Morrison DA. Book review: Tree thinking: an introduction to phylogenetic biology. Syst Biol. 2013;62(4):634-7.

Müller J, Scheyer TM, Head JJ, Barrett PM, Werneburg I, Ericson PGP, Pol D, Sánchez-Villagra MR. Homeotic effects, somitogenesis and the evolution of vertebral numbers in recent and fossil amniotes. Proc Natl Acad Sci. 2010;107(5):2118-23.

O'Meara RN, Asher RJ. The evolution of growth patterns in mammalian versus non-mammalian cynodonts. Paleobiology. 2016:42(3):439-64.

O'Rahilly R, Müller F. Developmental stages in human embryos. Washington: Carnegie Institution of Washington; 1987.

Padian K. How to win the evolution war: teach macroevolution! Evol Educ Outreach 2010:3:206-14.

Parsons TE, Downey CM, Jirik FR, Hallgrimsson B, Jamniczky HA. Mind the gap: genetic manipulation of basicranial growth within synchondroses modulates calvarial and facial shape in mice through epigenetic inter actions. PLoS ONE. 2015;10(2):e0118355.

Peter K. Normentafel zur Entwicklungsgeschichte der Zauneidechse (Lacerta agilis), vol. 4. Jena: Verlag von Gustav Fischer; 1904.

Pieretti J, Gehrke AR, Schneider I, Adachi N, Nakamura T, Shubin NH. Organogenesis in deep time: a problem in genomics, development, and paleontology. Proc Natl Acad Sci. 2015;112(16):4871-6.

Pough FH, Janis CM, Heiser JB. Vertebrate life. San Francisco: Benjamin Cummings; 2012.

Prothero DR. Evolution: what the fossils say and why it matters. New York: Columbia University Press; 2007

Raff R. The shape of life. Chicago: University Press; 1996.

Ramírez-Chaves HE, Wroe SW, Selwood L, Hinds LA, Leigh C, Koyabu D, Kardjilov N, Weisbecker V. Mammalian development does not recapitulate suspected key transformations in the evolutionary detachment of the mammalian middle ear. Proc Biol Sci. 2016;283:20152606.

Richardson MK. Vertebrate evolution: the developmental origins of adult variation. BioEssays. 1999;21(7):604-13.

Richardson MK, Gobes SMH, Van Leeuwen AC, Polman JAE, Pieau C, Sánchez-Villagra MR. Heterochrony in limb evolution: developmenta mechanisms and natural selection. J Exp Zool Part B Mol Dev Evol. 2009:312B:639-64.

Richardson MK, Hanken J, Gooneratne ML, Pieau C, Raynaud A, Selwood L, Wright GM. There is no highly conserved embryonic stage in the vertebrates: implications for current theories of evolution and development. Anat Embryol. 1997;196(2):91-106.

Richardson MK, Minelli A, Coates MI. Some problems with typological thinking in evolution and development. Evol Dev. 1999;1(1):5-7.

Rieppel O. Unterwegs zum Anfang. Zürich: Artemis Verlag; 1989. 
Rigato E, Minelli A. The great chain of being is still here. Evol Educ Outreach. 2013;6(18):1-6.

Safina C. There is more to evolution than natural selection. New York: New York Times; 2010.

Sakurai T. Normentafel zur Entwicklungsgeschichte des Rehes (Cervus capreolus), vol. 6. Jena: Verlag von Gustav Fischer; 1906.

Sánchez-Villagra MR. Developmental palaeontology in synapsids: the fossil record of ontogeny in mammals and their closest relatives. Proc R Soc B Biol Sci. 2010;277(1685):1139-47.

Sánchez-Villagra MR. Embryos in deep time. Oakland: University of California Press; 2012

Scammon RE. Normal plates of the development of Squalus acanthias, vol. 12. Jena: Verlag von Gustav Fischer; 1911.

Scheyer TM, Straehl FR, Sánchez-Villagra MR. Das Krokodil im Baum—Eine Ausstellung über Evolution und Biodiversität Zürich. Zürich: Scidinge Hall Verlag; 2015.

Scheyer TM, Werneburg I, Mitgutsch C, Delfino M, Sánchez-Villagra MR. Three ways to tackle the turtle: integrating fossils, comparative embryology, and microanatomy. In: Brinkman DB, editor. Morphology and evolution of turtles. Vertebrate paleobiology and paleoanthropology series. Dordrecht: Springer; 2013. p. 63-70.

Schmid U, Bechly G. Der Fluß des Lebens. Stuttgarter Beiträge zur Naturkunde C. Evolution. 2009; 66-67, 1-192.

Schoenwolf GC. Atlas of descriptive embryology. San Francisco: BenjaminCummings Publishing Company; 2008.

Scott EC, Branch G. Don't call it "darwinism". Evol Educ Outreach. 2009;2:90-4.

Sears KE. Novel insights into the regulation of limb development from "natural mammalian mutants". BioEssays. 2011;33(5):327-31.

Semon R. Zur Entwickelungsgeschichte der Monotremen. Denkschriften der Medicinisch-Naturwissenschaftlichen Gesellschaft zu Jena. 1894:5:61-74.

Shumway W. Stages in the normal development of Rana pipiens. Anat Rec. 1940;78(2):139-47.

Smith KK. Heterochrony revisited: the evolution of developmental sequences. Biol J Linn Soc. 2001;73(2):169-86.

Starck D. Vergleichende Anatomie der Wirbeltiere auf evolutionsbiologischer Grundlage: Band 1-3. Berlin, Heidelberg, New York: Springer-Verlag; 1979-1982.

Thewissen JGM. The walking whales: from land to water in eight million years. Berkeley: University of California Press; 2014.

Tokita M. Normal embryonic development of the Japanese pipistrell, Pipistrellus abramus. Zoology. 2006;109:137-47.
Tokita M, Abe T, Suzuki K. The developmental basis of bat wing muscle. Nat Commun. 2012:3:1302.

Tsukaguchi R. Zur Entwickelungsgeschichte der Ziege (Capra Hircus). Beiträge zur Entwicklung der Wiederkäuer. Anat Embryol. 1912;46(3):413-92.

Tyndale-Biscoe CH. Life of marsupials. Collingwood: CSIRO Publishing; 2005.

Völker-Brünn O. Normentafel zur Entwicklungsgeschichte des Ziesels (Spermophilus citillus), vol. 13. Jena: Verlag von Gustav Fischer; 1922.

Wägele JW. Foundations of phylogenetic systematics. München: Verlag Dr. F. Pfeil; 2005.

Wagner GP. What is "homology thinking" and what is it for? J Exp Zool Mol Dev Evol. 2016:326B:3-8.

Walter EM, Halverson KM, Boyce CJ. Investigating the relationship between college students' acceptance of evolution and tree thinking understanding. Evol Educ Outreach. 2013;6:1-8.

Wang Z, Han N, Racey PA, Ru B, He G. A comparative study of prenatal development in Miniopterus schreibersii fuliginosus, Hipposideros armiger and H. pratti. BMC Dev Biol. 2010;10:1-17.

Werneburg I. A standard system to study vertebrate embryos. PLoS ONE. 2009:4(6):e5887.

Werneburg I, Laurin M, Koyabu D, Sánchez-Villagra MR. Evolution of organogenesis and the origin of altriciality in mammals. Evol Dev. 2016:18(4):229-44.

Werneburg I, Maier W, Joyce WG. Embryonic remnants of intercentra and cervical ribs in turtles. Biol Open. 2013a;2(11):1103-7.

Werneburg I, Polachowski KM, Hutchinson MN. Bony skull development in the Argus monitor (Squamata, Varanidae, Varanus panoptes) with comments on developmental timing and adult anatomy. Zoology. 2015;118(4):255-80.

Werneburg I, Sánchez-Villagra MR. The early development of the echidna, Tachyglossus aculeatus (Mammalia: Monotremata), and patterns of mammalian development. Acta Zool. 2011;92(1):75-88.

Werneburg I, Spiekman SNF. Mammalian embryology and organogenesis. From Gametes to Weaning. In: Zachos F, Asher RJ, editors. Mammalia. Berlin: de Gruyter; (in press).

Werneburg I, Tzika AC, Hautier L, Asher RJ, Milinkovitch MC, Sánchez-Villagra MR. Development and embryonic staging in non-model organisms: the case of an afrotherian mammal. J Anat. 2013b;222(1):2-18.

Zachos FE. Tree thinking and species delimitation: guidelines for taxonomy and phylogenetic terminology. Mamm Biol. 2016;81(2):185-8.

Zrzavý J, Storch D, Begall S, Mihulka S, Burda H. Evolution. Ein Lese-Lehrbuch. 2nd ed. Heidelberg: Springer; 2013.

\section{Submit your manuscript to a SpringerOpen ${ }^{\circ}$ journal and benefit from:}

- Convenient online submission

- Rigorous peer review

- Immediate publication on acceptance

- Open access: articles freely available online

- High visibility within the field

- Retaining the copyright to your article

Submit your next manuscript at $\boldsymbol{\nabla}$ springeropen.com 